\title{
占領期札幌におけるキャンプ・クロフォードの建設経緯とその特徵について \\ A HISTORICAL STUDY ON CONSTRUCTION PROCESS AND ITS FEATURES OF CAMP CRAWFORD ON GHQ'S OCCUPIED DAY IN SAPPORO
}

\author{
角哲*1, 大場 修*2, 砂本文彦*3, \\ 玉田浩之*4, 村上しほり*5, 長田城治*6 \\ Satoru KAKU, Osamu OBA, Fumihiko SUNAMOTO, \\ Hiroyuki TAMADA, Shihori MURAKAMI and Joji OSADA
}

\begin{abstract}
This paper's purpose is to clarify the construction process and the following features of Camp Crawford in Makomanai, Sapporo. First, the GHQ recognized the importance of the camp in the Cold War. Therefore, its construction was of high priority thus completed quickly. Second, contractors organized a special union which is reminiscent of the JV. Third, the camp's DH and TH areas were developed simultaneously, as a result, was evaluated as "too expensive." However, it had numerous facilities. Furthermore, existing buildings and roads were used with new buildings made simple. Lastly, it is the foundation of the present suburban residential area.
\end{abstract}

keywords:After World War II, Hokkaido Prefecture, Sapporo, GHQ, occpied, Camp Crawford 戦後, 北海道, 札幌市, 連合軍総司令部, 占領, キャンプ・クロフォード

1. はじめに

本稿は, 占領期の札幌で豊平町真駒内（現札幌市南区真駒内）に 建設された占領軍基地「キャンプ・クロフォード」(Camp Crawford) の建設経緯と特徴を明らかにすることを目的とする ${ }^{1)}$.

調達庁の『占領軍調達史』 ${ }^{2-3)}$ が記す様に, 占領期の日本では全国 各地に占領軍基地が建設された. 占領軍基地は，宿営地として進駐 間もなく建設された兵士用の「かまぼこ兵舎」（Quonset hut）が中心 のもの, 1946 年 3 月 6 日の占領軍の要求を受けて新設された家族住 宅 (Dependent Housing:DH) が中心のものに大別され，特に戦災を受 けた占領施策上重要な拠点都市に多く建設される傾向にある. 東京 のワシントン・ハイツ（現代々木公園）は DH の代表例である注1).

占領軍基地に関する建築・都市分野の成果の一つに小泉和子ら 注2) の論考があり，占領軍設計部門がまとめた 2 冊の “Dependents Housing Japan \& Korea"4-5) (以下, “DH”) の分析を通じて, DH に戦 後日本における住宅や住宅地の原点を見出した．この成果は，占領 期日本の建築や都市を理解する上で, 占領軍基地が見逃すことので きない対象であることを示している.

とはいえ，調達庁や小泉らの成果は，占領軍基地の建設方針や東 京の事例を知る上で有効であるが, 地方の情報は限られる。もちろん， 占領軍は連合国軍総司令部（General Headquarter:GHQ）を筆頭に組 織立てられていたから，日本の占領拠点である東京の様相を把握す ることで，地方についても一定程度理解できるだろう。しかし，都 市毎に占領施策の重要度や戦災状況, 都市ストックは異なり, その
一端は建築や都市という実空間に反映されたと想像される.よって, 占領期日本の建築や都市の実態を把握する手がかりの一つとして, 地方の占領軍基地について明らかにすることは有効であると考える.

こうした背景から, 筆者らは東京と横浜を除く地方の占領軍基地 や接収施設に関する報告注 ${ }^{3)}$ や論考 ${ }^{6)}$ を公表してきた。特に，占領期 日本の部隊配置と基地建設に関する論考 ${ }^{7)}$ では, 全国の基地の設置 状況を明らかにしたが, 個別事例の研究は課題として残した.

本稿が札幌市を対象とした理由は 2つある.まず，当初東日本を 管轄する第 8 軍の拠点であった札幌市は，西日本を管轄する第 6 軍 の拠点であった京都市と同じ非戦災都市であるため, 戦前の都市ス トックが遺存する都市という点で他の主要都市と異なることである. また, 所謂 6 大都市に数えられる京都市に対し, 札幌市は地方かつ 積雪寒冷地という点で異なることである.

北海道の占領軍基地の中で，札幌市近郊真駒内の北海道立種畜場 （以下，種畜場）と千歳村（現千歳市）の旧日本海軍航空基地を接収 して新設された 2 力所は, 『占領軍調達史』が DH の新設予定地とす る重要な拠点であった．この内，前者は 1946 年 5 月から翌年にかけ て建設され，1880 年に小標・手宮＝札幌の鉄道を敷設したアメリカ 人技師の名を冠して「キャンプ・クロフォード」と名付けられた

キャンプ•クロフォードについては, 『北海道米軍太平記』 ${ }^{8)} や 『$ 新 札幌市史』 ${ }^{9}$ 等の郷土史, 喜田信代らの現存兵舎注4) や石川洋介らの 北海道立種畜場施設を転用した基地内の施設注 ${ }^{5)}$, 筆者らの札幌市の 接収施設といった建築. 都市分野の研究報告等が触れている. 中でも,
*1 名古屋市立大学大学院芸術工学研究科 准教授 - 博士 (工学)

*2 京都府立大学大学院生命環境学研究科 教授・工博

*3 神戸女子大学家政学部 教授・博士(工学)

*4 大手前大学メディア・芸術学部 准教授・博士(学術)

*5 大阪市立大学大学院生活科学研究科 客員研究員・博士 (学術)

*6 郡山女子大学家政学部 講師・博士 (工学)
Assoc. Prof., Graduate School of Design and Architecture, Nagoya City Univ., Ph.D. Prof., Faculty of Life and Environmental Sciences, Kyoto Prefectural Univ., Dr.Eng. Prof., Faculty of Home Economics, Kobe Women's Univ., Dr.Eng.

Assoc. Prof., Faculty of Media and Arts, Otemae Univ., Ph.D.

Visiting Researcher, Graduate School of Human Life Science, Osaka City Univ., Ph.D. Lect., Dept. of Human Life Studies, Koriyama Women's Univ., Dr.Eng. 
廣田によると, キャンプ・クロフォードの建設に従事した占領軍 の技術系将校は, 当初 $4 \sim 5$ 名, 軍属の技術者は土木と建築が各 1 名で, 種畜場の試験研究庁舎を建設本部として作業を進めた ${ }^{10)}$. また, 顧問格の建設隊本部技師に元道庁技師の福岡五一注 ${ }^{14)}$ が就いた.こ の事実は, 占領軍が自らの設計基準に固執せずに「地理的条件を勘案」 して地元の技術や経験を導入した証左といえる.こうした日本側の 人的な技術協力は, 他の占領軍工事に共通する対応である ${ }^{\text {注 }}{ }^{15)}$.

日本政府の特別建設出張所設置により, 道庁には 1946 年 5 月 19 日, 土木部に「特別建設事務所」が設けられた. その建築担当が廣田であっ た. また, 10 月の戦災復興院への一元化に伴い, 「真駒内住宅兵舎関 係工事は道庁が担当して居つたが十月一日中央命令に依り終戦連絡 事務局にて担当して居つた接収家屋の改造工事並に兵舎飛行場其の 他の建設工事は中央に於ては復興院所管となり之が工事の実際担当 は土木部が施行する」 ${ }^{13)}$ と道庁の業務も拡大した.

キャンプ・クロフォードの工事は 1946 年 5 月の測量に始まるが, DH の建設戸数は推計の約 $45 \%$ の 210 戸に減じた ${ }^{4-5)}$. その理由は不 明であるが, 日本政府が物資不足を理由に宿舎数等の緩和を陳情し, 5 月 18 日に 1946 年の建設目標が 1 万戸に半減した影響と考えられる 注 ${ }^{16}$. 但し, 1946 年 12 月末の全国の DH の戸数は 3,172 戸 (新築 1,200 戸), 1947 年 3 月末は 6,800 戸と推計され注 17$)$, 建設目標が半減して もな打占領軍の要求の充足は困難であった，注目すべきは, この工 事が 5 月 13 日の戦災復興院による「進駐軍用家族住宅設計図に関す る件」の配布や日本政府の DH 建設戸数の調整の最中に着手された ことで, 占領軍がキャンプ・クロフォード建設を急いだことを示す.

\section{2. キャンプ・クロフォードの用地選定とその背景}

キャンプ・クロフォード（Fig.1）の用地となった種畜場は, 開拓 使の打雇い外国人エドウィン・ダン (Edwin Dun) の指導で開場し 注 ${ }^{18)}$, 札幌農学校 (現北海道大学) 附属農場等と並ぶ日本の近代農業 を先導した重要な農場の一つであった.

その位置は札幌市の南方約 4 6km, 豊平川がなす扇状地の要付近 で市街地から独立していた。. 地形は, 東の右岸が $2 \mathrm{~km}$ 程で丘陵地に

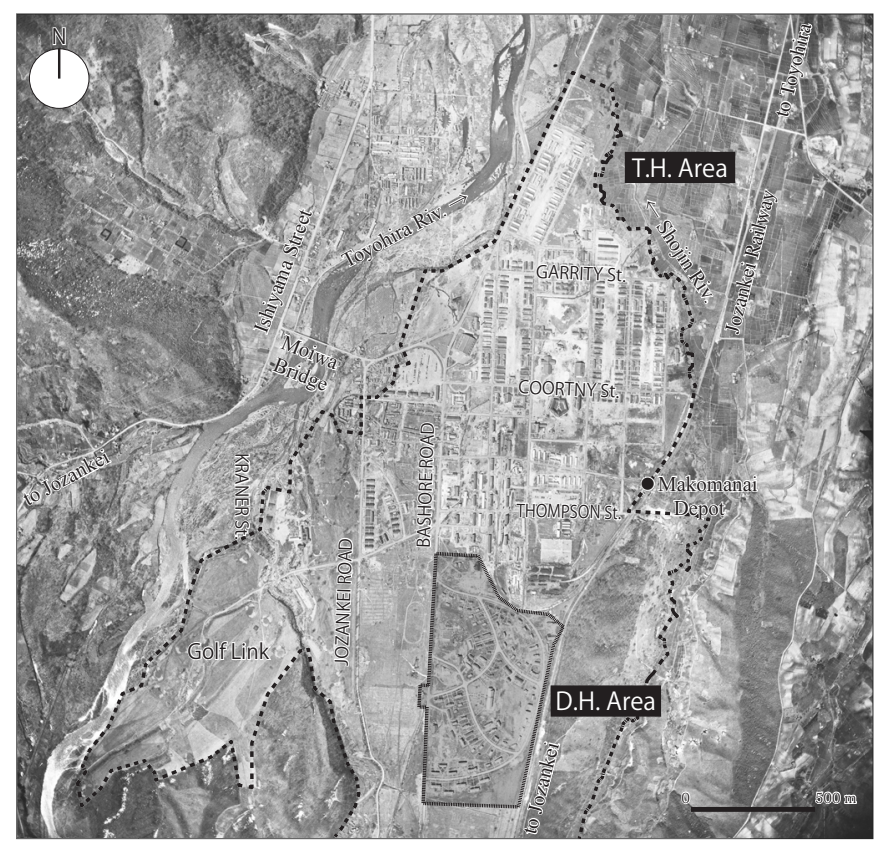

Fig.1 Airial View of Camp Crawford in Makomanai, Sapporo, 1948 (UR246_CA-134, 22 Apr. 1948 owned by Geospatial Information Authority of Japan)
至る緩やかな傾斜地, 西の左岸が藻岩山山麓にかかる丘陵地である. また南北の起伏は小さいが, 流路に従い南から北へ緩やかに低くな る微地形である. 種畜場の主要機能は比較的平坦な右岸にあり, キャ ンプ・クロフォードの主な施設も右岸に設けられた.

郷土史から用地選定の経緯をおうと, 札幌土建協会の技術担当で 元道庁技師の吉田三郎平は, 占領軍が駐留する豊平町月簺 (現札幌 市豊平区月寒）の旧日本陸軍師団司令部注 ${ }^{19)}$ を訪問した際，新設基 地の候補地として未開地の三角山付近に印がある地図を目にした。 そこで吉田は 1946 年 1 月着任の占領軍のキャンプ設営担当者に, 当 地には人家や墓地があることを理由に注20) 真駒内の選定を進言した 注21).この訪問との前後関係は不明ながら, 道庁は種畜場が候補にな るとその重要性に鑑みて月寒や三角山を代替地に示したというから, 占領軍はこの 3 力所から真駒内を選定したことになる. 候補地が全 て郊外であるのは, 札幌市が非戦災都市の為, 市街地やその周辺に 十分な土地がなかった為と思われ, 名古屋注 22$)$ や神戸注 23$)$ 等の戦災都 市で, 市街地の焼け跡に基地を建設したことと対照的である.

ここで, 占領軍が真駒内を選定した背景を考えてみたい. まず占 領軍と日本政府は, 用地選定の検討項目を設けていた。例えば, 前 節で触れた「軍内指令」は, A 位置, B 建築形式, $\mathrm{C}$ 配置, D 建物の 間隔, $\mathrm{E}$ 厚生地域, $\mathrm{F}$ 附属施設, $\mathrm{G}$ 附帯施設の 7 項目, 戦災復興院の 「通牒」は「特に既設の道路, 上下水道, 電気, 瓦斯等の諸施設の利 用関係に十分留意されたい」 ${ }^{3)}$ と示し，これらが選定条件となった.

これに対し, 廣田は建設を担当した第 11 空挺団がノースカロライ ナ出身の為, 故郷の牧歌的風景を彷彿とさせる真駒内を選定し「コ ロニアルスタイルの一大基地を設営する夢を描いたのではなかった のであろうか」と推察する注 ${ }^{24)}$. しかし, 札幌市近郊に牧歌的風景は 多々あったはずで, 感傷的な理由で決定したとは考え難い.

また, 奥田二郎は, 演習地と污水処理, 山紫水明 ${ }^{8)}$ を理由にあげる. つまり, 訓練用の十分な用地と衛生, 良好な居住環境を重視したと の理解である. 確かに豊平川上流には江戸末期に開湯した定山溪温 泉があるが大きな集落はなく, 衛生と居住の面で良好な環境を望め た.さらに, 占領軍はキャンプ・クロフォード建設の際に藻岩山山 麓で取水して上水を確保し, 延長 $18 \mathrm{~km}$ の下水道を敷設して豊平川へ 流したが, 三角山付近と月寒にはこれに比肩する河川がない.

この他, 工期短縮の可否も選定の一因と考えられる. 占領軍は米 ソ関係が「相当緊迫」していた為, 1947 年 2 月頃に「不急工事」を 中止し ${ }^{\text {ì } 25)}$, 「純宣事的見地から重要と目される事業に全力が傾注」 した. その一つが真駒内で, 三沢や鹿屋と並び「大兵舎計画（約四， ○○坪）実現の為, 中央 PDにより資材の急送が命ぜられた」喫緊 の工事であった．特に全国の基地建設で「最も問題をおこしたもの の一つに, 資材問題」 ${ }^{2)}$ があったが, 調達が優先されたことからその 重要性が理解できる。つまり, 占領軍には開墾済みの種畜場を接収 することで, 用地造成の手間を省く意図があったと思われる. 後述 の通り, 実際の計画で占領軍は既存の農場施設や場内道路を活かし ており,このことも工期短縮に寄与しただろう注 26). なお, 戦災/非 戦災の違いこそあれ, 市街の焼け跡 (現白川公園) を用いた名古屋 や琵琶湖を望む山麓の田畑を用いた大津市の皇子山ハイッ主 27) 等も, 造成済の用地を利用して建設した点が共通する。

3. キャンプ・クロフォード建設の組織と工事 
本章では, キャンプ•クロフォード建設の組織を全国の動向と比較, 整理した上で, 工事の内容を追ってゆく.

\section{1. キャンプ・クロフォード建設の組織}

占領期の日本において, 占領軍は接収施設の改修等, 全国で多量 の工事を発注した. 当初, 民間業者は独自に占領軍や戦災復興院と 交渉して工事を受注していたが，その方法は徐々に体系化された 28). また, 占領軍基地の建設も民間業者が受注して工事を進めた.

『占領軍調達史』によると ${ }^{3)}, 1946$ 年 4 月 29 日の「家族住宅建設 の請負業者選定に関する件」で DH 建設を一任された日本政府は, この工事が「末経験の一大建設事業」で, 直営による実施が難しい為, 民間業者に協力を仰いだ。一方，民間業者の全国組織である日本建 設工業統制組合は, 基地建設が「一般復興主事に優先して実施される」 と認識し, 民間業者への発注を日本政府に陳情して受注の準備をし ていた．また，同組合理事長の竹中藤右衛門らは，6月 1 日に特建協 力会等を組織した ${ }^{\text {注 }} 29$. 竹中は, 当該工事を受注しなければ仕事がな いとの危機感から，6月15日に「進駐軍宿舎建設について」と題す る談話を発表し，「個々の業者との直接折衝を避けて，建設地方の実 情に最も精通する当組合支部を活用」することを「本工事施工上の 要諦」と訴えた，元々「連合軍用宿舎等建設要綱」は「施工は原則 として請負…地方庁に於い方契約す．請負契約は随意契約」 ${ }^{3)}$ と記 すから, 業者間の競争を避ける狙いもあったと推察される. さらに, 占領軍の工事は発注から着工までの期間が短く実質的に見積が不可 能で入札の余裕がなかった ${ }^{2}$ ことも, 民間業者の危機感の一因だろう. この様に, 民間業者が占領軍工事を公平に受注し, 共存共栄を図ろ うとした ${ }^{\text {注 }}$ ) ことは, 戦後混乱期の建設工事の特徵の一つといえる.

キャンプ・クロフォード建設にあたり，道庁が特別建設事務所を 設置した一方，民間業者は札幌土建協会の主導で，真駒内建設局（以 下, 真建) を組織した. 真建には, 伊藤組, 大林組, 川口組, 木田組, 菅原組, 第一土建, 大成建設, 田中組, 鉄道工業, 成島組, 廣野組 が参加し, 後に鹿島建設, 清水建設, 杉山建設, 山田組等が加わった. 真建は, 設備業者を加えると 40 社近い組織で, 最盛期の人員は 170 〜 180 人, 労働者は 6,400 人を数えたという注31). 初代局長は伊藤組 社長で貴族院議員等を歴任した伊藤豊次, 1947 年からは元道庁土木 部長で田中組の宮崎正雄が就いた. つまり, キャンプ・クロフォー ドの建設は, 竹中の訴えの通り,「地方の実情」に明るい人物を中心に, 官民の組織を両輪に進んだ。

特筆すべきは，真建を窓口に一括して工事を受注して参加業者に 配分したことで「全国に例がないほどの成功」注 ${ }^{33}$ と評された.こ の方法はジョイント・ベンチャー方式 (Joint Venture:JV) の萌芽とい えよう。JV 方式は 1950 年代の沖縄工事で始まり, 1957 年頃から「大 規模工事に続々採用」されたから注 32 , 真建は戦後一般化する施工方 式を約 10 年先取りしたことになる. その中で全体の $70 \%$ を担当した という注 ${ }^{34)}$ 大成建設の社史は, 同社が真建設立を提唱し, 全国のキャ ンプ工事に波及したとする注35). 同社の提唱か否かは確認できないが, 同じく工事を急いだ三沢基地の工事関係者が見学に訪れたというか ら注36)，この方式が一定の影響力をもったことは確かである.

3.2. キャンプ・クロフォードの建設工事

特別建設事務所と真建は, 占領軍作成の 1:3,000 の配置図を元 に 1946 年 5 月から測量と設計を進め, 6 月下旬から兵舎 (Troop Housing:TH), DH の順で建設したという。 なお，英語表記の Fig.2の
Table 2 Outline of Construction about Camp Crawford

\begin{tabular}{|c|c|c|c|c|c|c|c|}
\hline \multirow{2}{*}{\multicolumn{2}{|c|}{$\begin{array}{l}\text { Site Area } \\
(\text { tsubo })\end{array}$}} & \multirow{2}{*}{$\begin{array}{c}\text { Const. Cost } \\
\text { (JPY) }\end{array}$} & \multicolumn{5}{|c|}{ Const. Detail } \\
\hline & & & Bldg. Num. & Area (tsubo) & Road & Sewer & Landscape \\
\hline Total & 480,000 & $1,212,000,000$ & 471 & 43,748 & $25,444 \mathrm{~m}$ & $19,307 \mathrm{~m}$ & \\
\hline D.H. Area & 13,000 & $259,000,000$ & 104 & 9,288 & $3,844 \mathrm{~m}$ & $3,377 \mathrm{~m}$ & $9,700 \mathrm{~m}$ \\
\hline T.H. Area & 350,000 & $953,000,000$ & 367 & 34,460 & $21,600 \mathrm{~m}$ & $15,930 \mathrm{~m}$ & $7,650 \mathrm{~m}$ \\
\hline \multicolumn{3}{|c|}{ Construction Period (original plan) } & Start & 3 Jun 1946 & Completion & 31 May 1947 & about 1 year \\
\hline
\end{tabular}

下図は，縮尺に鑑夕，この配置図と推察される。

『長官事務引継書』 ${ }^{13)}$ 掲載のキャンプ・クロフォード建設の工事 概要（Table 2）によると，工事は DH 地区 130,000 坪に住宅を 104 棟 （9,288 坪）, TH 地区 350,000 坪に兵舎を 367 棟（約 34,460 坪）を建 設する計画で, 各々の地区に道路, 水道を敷設した他, 造園工事や 暖房, 電気等の附帯工事もあった. また, 工事には小型機の滑走路（延 長 700m）やゴルフ場の整備も含まれたと思われる.

公式の着工日は 1946 年 6 月 3 日, 竣工目標は 1947 年 5 月 31 日 であるから, 工期約 1 年と急を要するものであった。 また, 占領軍 は DH の工期を第 1 期 35 戸，第 2 期 63 戸と区切り ${ }^{13)}$, DH と TH の $40 \%$ を 1946 年 12 月に使用できる様に厳命した。 さらに，『長官事務 引継書』に記される工事の進捗は, 1947 年 2 月 ${ }^{12)} に 80 \%$ であるが, 4 月 ${ }^{13)}$ には $65 \%$ に後退した. 正確な竣工日は判然としないが, 1947 年 7 月や「秋」,「予定どおり 22 年末」 ${ }^{10)}$ 等と着工から約 1 年 $2 \sim 6$ 力 月程で完成したことになる.

ここで, 工事が遅延した理由と, 遅延しつつも比較的早く竣工で きた背景を検討する，まず，遅延は短い工期が最大の要因といえる が, 人材不足もあった。例えば, 1947 年 3 月 20 日に札幌日傭勤労署 の出張所が真駒内に開設され ${ }^{9}$, 校舎が接収されて授業が受けられな い高校生の奉仕もあった ${ }^{\text {注 }}$. $。$ 。た, 道庁では設備技師が不足し, 南 満洲鉄道に勤務していた引揚者が「暖房等の設備工事を主導」した という ${ }^{10)}$. 北海道では戦前に満洲の採暖方法として壁式ぺチカが導 入され主 38 , 戦後は引揚者の受入拠点となったから, 専門知識を有す る人材の確保も可能であったと想像される. なお, 採暖方式について, 当初, 占領軍は電気暖房を要求したが, 日本政府の陳情で 1946 年 7 月 1 日にガス, スチーム, 電気が各々 $1 / 3$ になり, 9 月 20 日にガス $16 \%$, スチーム $56 \%$, 電気 $28 \%$ となった ${ }^{2)}$.

暖房以外の寒冷地の仕様も工事遅延の一因といえる. 廣田による と, 軍用規格図集掲載の TH はツーバイフォー材の枠組にベニア板を 張った仮設建築で ${ }^{10)}$, ベニアの厚さは $1.5 \sim 2$ 分 ${ }^{2)}$ であった. しかし, キャンプ・クロフォードでは「かなり本格的なものを要求」 ${ }^{10)}$ され, 基礎は RC 造, 外壁は煉瓦であった. 真偽は定かでないが, この特徵 的な仕様はアイケルバーガー中将と建設担当の 11 空挺団司令官スイ ング少将が士官学校の同期という理由で容認されたという注 39$)$.なお, 「設計が贅沢に過ぎると思われる事例」として日本政府が GHQ にあ てた陳情書に掲載した中で, 青森の TH は, $23^{\circ} \mathrm{C}$ の室温を保持する為, 特別に作る必要のある 4 分厚のベニアにフェルトを貼った「寒地北 海道よりも規格が高い」もので, 岐阜の 2 重空は「一寸勿体ないも のと思われる」仕様 $\left.{ }^{2}\right)$ と, 他の都市にも特別な仕様が散見されるが, キャンプ・クロフォードの仕様は大きく異なった.

一方, 工事が遅延しつつも比較的早く竣工した理由の一つは, 2.2 で触れた工事用資材の優先的な調達である.『占領軍調達史』によ ると, 資材は日本政府が調達や配分する「宿舎 $(\mathrm{DH})$ 工事用資材 $=$ LD 資材」と「軍需資材として占領軍から全部支給されるのが原則」 
の「兵舎 $(\mathrm{TH})$ 一般工事用資材 $=\mathrm{PD}$ 資材 $\lrcorner$, 「補給物資（補給部資 材)」の 3 つがあり, PD 資材は持ち出しもあったという注40). キャン プ・クロフォードでは 1946 年 11 月にセメント製造用石灰, 12 月 4 日にセメント, 1947 年 5 月 19 日に米軍供給の煉瓦を横浜から積出し 小樽で荷揚げする等 ${ }^{16)}$ 優先された. なお, 敷地の東を走る私鉄であ る定山溪鉄道を工事用に分岐して引込線を設けたことも特別な対応 の一環といえよう注 41)。 また, 施工方法も一因で, 民間業者は米軍貸 与の重機を用いて工事を進めた ${ }^{10)}$ 。これは全国に共通し, 業者は「米 国流の最新施工技術や建設機械等に接するチャンスに恵まれ」注 42 , 「土木工事の機械化のあけぼのをみた」注43) と, 戦後の施工技術に影 響を及ぼした ${ }^{\text {注 }}$.

3.3.「贅沢すぎる」キャンプ・クロフォード

アイケルバーガー中将がキャンプ・クロフォードを「贅沢すぎる」 と評したことは郷土史が度々触れる事実である注45). 何が贅沢かは整 理が必要であるが, 彼は 1947 年 5 月 26 日に現地を訪問しているから, 発言はその時のものだろう。訪問に先立ち, 担当部隊は自ら建設中 の基礎を壊して土に埋め, 完成予想の透視図を破棄したという.そ

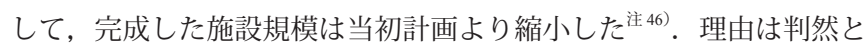
せず想像の域に止まるが, 11 空挺団は第 8 軍司令部が承認した仕様 を無断で変更して工事を進めたが, 彼らの予想に反する訪問の一報 を受けて事実を隠したのではないか. というのは, アイケルバーガー 中将の札幌訪問の目的は, 4 月の選挙で初の公選知事に就いた社会党 の田中敏文との面会だったからである湦 ${ }^{47)}$. また, この顛末を踏まえ ると, 『長官事務引継書』が記す工事進捗割合の後退にも説明がつく.

また，「贅沢」を理解する手がかりとして，まず DH の敷地規模に 注目すると, キャンプ・クロフォードの 1 戸当りの面積 1,700 mは, 設計標準 $600 \mathrm{~m}^{2}$ の 3 倍近い.これは「設計が贅沢に過ぎると思われ る事例」 2) 9 つの中で最大で, 2 位の朝霞で $1,330 \mathrm{~m}^{2}$ と標準の 2.2 倍程 度であった. 次に工費に注目すると, 真駒内の部隊規模は, 1947 年 11 月 15 日現在, 東京の $\mathrm{GHQ}$ を除く全国 50 のキャンプで 14 番目と ${ }^{7)}$ 決して大きくないが, 工費 121,200 万円は, 1946 年 12 月 16 日現在 「軍事施設で全国的に金のかかつているもの」23 事例の最高額で, 2 位は春日原の 73,600 万円, 3 位は朝霞の 67,900 万円, 最低は太田の 5,000 万円であるから群を抜いている ${ }^{3)}$. この内, 福岡市南東約 $8 \mathrm{~km}$ の旧軍用地に建設した春日原は, 近接する板付空軍基地 (現福岡空港) の通信施設を持ち, キャンプ・クロフォードと同じく DH と TH の両 地区を備ており (1972 年返還), 工費は $60 \%$ 程であるが, 両地区を 一体として開発したことが高騰の理由と思われる，但し，工費が嵩 んだ要因は占領軍の工事発注方法にもあった. 調達要求は「○○建設 の整備拡張」等「漠然とした抽象的なもの」で, 具体的な工事は現 場責任者がその都度出す「作業命令書」で初めて明らかになり，「費 用を考慮せず際限なく発出」された. よって, 事前の工費を算定は 不可能で「精算を行つてはじめて工事費の大きいのに一驚すること も，むしろ一般的であつた」という注 48). いずれにせよ，DH の敷地 規模と工費の両面でキャンプ・クロフォードが目立っている.

\section{4. キャンプ・クロフォードの空間構成と施設配置}

本章では, 北海道立文書館と札幌市公文書館が所蔵する配置図注 ${ }^{49)}$, 国土地理院の空中写真からキャンプ・クロフォードの空間構成を 整理し, ”DH”やNARA の写真, 『開拓使・北海道庁営繥 80 年の覚書き』
から施設配置を把握する.

\section{1. キャンプ・クロフォードの空間構成}

一般に, 占領軍基地は DH 地区と TH 地区に大別できることは先に 指摘した. 両地区は独立する場合が多いが, 岡山主 50) の様に接収住 宅を DH に充てるだけの場合もあるし，部隊規模の大きな神戸には 2 つの独立した $\mathrm{TH}$ 地区があった ${ }^{7)}$ 。 また，基地には占領軍の任務遂行 と生活の便宜を整える為に「事務所, ホテル, モータープール, 飛 行場, 専用道路, 劇場, ゴルフ場, PX, 教会, 学校, 病院, ベーカリー, ランドリー, 専門電気, ガス, 水道施設」2) 等が設けられ, 内田青 蔵は一連の施設が揃った DH 地区を「小規模ながら一つの都市」注 51$)$ と評し, 占領軍基地が住宅地を超えた開発であることを示唆する.

これに対し, キャンプ・クロフォードは両地区一体の開発である 点に特徴がある (Fig.2). 区画には番号が振られ, TH 地区は 100 〜 2900 (2000，2300，2600，2800 は未確認)，3700～4000の 29 区画, DH 地区は 3000 から 3600 までの 7 区画がある. また, 各施設には上 1-2 桁が地区番号に対応する3-4 析の施設番号が付された.

全体の空間構成を整理すると, まず主要施設は豊平川と定山渓 鉄道の間に設けられた ${ }^{2}$. $。$ このエリアは「く」の字状に南北に走 る BASHORE ROAD が全体を大きく東西に区分する．この道路と THOMPSON STREET, JHONSTON ROAD の 3 本は種畜場の道路で あるから ${ }^{14)}$, 占領軍は既存道路を計画の基準にしたといえる. また, BASHORE ROAD の東は, 定山溪鉄道から分岐する引込線が北の TH 地区と南の DH 地区に分けている．地形的に豊平川の影響でわずか ながら南と東が高く, 北と西が低いから, 居住者の職位の高い DH 地区が TH 地区よりも高いことになる. 一方, BASHORE ROAD の 西は, 北から南の順に旧りんご園の(2)野球場（3700 区，囲い数字は Fig.2 の施設に対応), 旧採草場の(5)モータープール, 真駒内神社のあ る日本人労働者居住地, RPE SHOP AREA と独身幹部宿舎 (2200区) に分かれ，西には豊平川支流の真駒内川を跨ぐゴルフ場（2100区） や(1)テニスコート, 滑走路 (3800区) がある. この様に, 高燥な東 に執務中枢と居住の機能, 河川に近い低地の西に生活施設と娛楽施 設が配されている.

\section{2. 宿舎 $(\mathrm{DH})$ 地区の施設配置}

DH 地区（Fig.3）は南北最大約 $1,000 \mathrm{~m}$, 東西最大約 $500 \mathrm{~m}$ で, 元は 「一哩馬場」であった，全体は西端の BASHORE ROAD を基準に半円 状に走る REID ROAD と, それに交差する RANGEL ROAD, SKAU ROAD, KRAINS ROAD の 3 本の曲線道路, 定山渓鉄道と引込線で 7 区画に分かれる，道路はコンクリート舗装で, 路側に雨水溝があり, 歩道も設けられた（Fig.4). 中央の区画（3400区）を例に施設配置を みると, 中央に(1)学校 (3419) とそのグラウンドを兼ねた広場があり, 20 棟 38 戸の DH が十分な間隔を持って区画を囲繞している注 53 . DH 周辺は芝で満たされ，歩道が各戸へ通じていた。

また，基本的に 1 戸建と 2 戸建の DH は独立しているが, RANGEL ROAD と KRAINS ROAD の中程にある 2 戸建 1 棟と 4 戸建 2 棟の各 3 棟は共有の中庭を囲んでいる. DH の並ぶ 3100 区（21 棟 37 戸), 3200 区 (22 棟 37 戸), 3500 区 (22 棟 65 戸), 3600 区（5棟 20 戸) も概ね同様の配置である. 複数の棟を組にして中庭を囲む配置は, “DH”が示す通り他の占領軍基地に共通し ${ }^{4-5)}, 3100$ 区は 5 棟で $1 つ$, 3600 区は 5 棟で 2 ついう様に, 組合せに変化がつけられた。但し, 曲線道路を基準にした配置の為, 接道と採光の方角は一定ではない. 
なお，3300 区の定山渓鉄道と引込線に挟まれる北東角に使用人宿舎 (2) (3300-3303) とボイラー室がある. 他のボイラー室は 3000 区, 3100 区, 3500 区に, 消防署(3)（3526）とジープ車庫は 3500 区にある.

ところで，“DH"4-5) は “TYPICAL LAYOUT” と題する図と文章を掲 載し, 施設配置で考慮すべき 6 つ要点（道路, レクレーション地域, 共同施設, 居住地, ランドスケープ, 歩廊) を示す。これらをキャンプ・ クロフォードと比較すると, 道路は地形に応じて曲線にすることい う要点に準じているが, 敷地は概ね平坦の為, 地形をどう解釈した かは不明である. また, レクレーション地域の内, 野球場やテニス コート等規模の大きい広場は学校のグランドを兼ねること, 共同施 設の消防署は各施設に速やかに到着できる位置であること, 雇用人 宿舎やサービス機能は住宅と離して設置すること, ランドスケープ は芝生と街路樹を備えることが要点で，いずれも準じている。一方, 共同施設では劇場や PX，教会等の施設は駐車場と共に利便性の高い 中央に配することとするが，学校と広場を除く施設を TH 地区に設 けた点が異なる.

さらに，BASHORE ROAD に面する 1700 区と 2400 区が飛地であ ることも特徵で, 前者は種畜場事務所（現エドウィン・ダン記念館） を改修して(5)社交クラブとし, 後者は(4)広場である.つまり, 住宅 は一つの空間として完結させたが，それ以外の施設は一体化に拘ら ず，点在する既存施設を柔軟に転用したのである.

\section{3. 兵舎 $(\mathrm{TH})$ 地区の施設配置}

TH 地区は東西約 $1,800 \mathrm{~m}$ ，東西約 $1,300 \mathrm{~m}$ で，東西の STREET と南 北の AVE. が格子状の区画をなす．但し，元は採草場であった北西の
200 区が豊平川の流路の影響で角度が振れている様に，区画の方角や 規模にはばらつきもある，道路の大半はアスファルト簡易舗装で，路 側に雨水溝がある(Fig.5). 各区画には 1 中隊を単位に TH を配置する. 具体的には平行配置の 24 人用の兵舎各 3 棟が食堂 1 棟と休養室 2 棟 を挟んだ組を 1 単位とし，1 区画に 4 組を並べる（200，800，1000， 1100 区，Fig.2 右下)。しかし， $\mathrm{TH}$ の数が 4 棟の区画や東西が基本の TH の主軸が南北となる例外もある.

TH 以外の施設として，1400 区に(1師団司令部（1401）や( 教

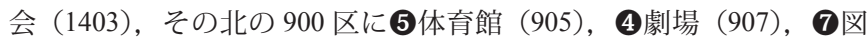
書館（908), 6クラブ (909), フットボールと野球の(3)グランド等 がある.また，西の 1300 区に9 PX（1303，Fig.6）や10ベーカリー (1302), (1)郵便局もある.これらは TH 地区の中心であり, キャンプ・ クロフォード全体の機能的な中枢でもあった，また，南北に隣接す る 2400 区と 2900 区の牛舎等, 種畜場の転用施設があり, その詳細 は石川らの報告に詳しい。但し，『旧真駒内施設接収関係』 ${ }^{14)}$ による と，接収時の種畜場施設は 140 棟であったが，1946 年度 34 棟，1947 年度 32 棟十サイロ 3 棟, 1948 年度 18 棟と順次解体して 1950 年 1 月

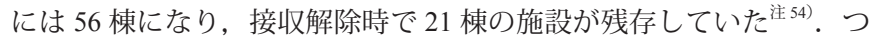
まり，一部の既存施設は急を要する建設に役立てられたが，不要な 施設は竣工後に整理された。 なお, 119 棟の内 96 棟は杉山組土建が 取壊し, 1947 年 5 月まで解体部材の一部は種畜場機能の移転先であ る新得町で「復旧工事用資材として」使用したという ${ }^{16)}$.

また，豊平川に近く敷地の低い BASHORE ROAD 西の 2200 区は， 独身幹部宿舎の地区で，3 本の道路で囲まれる三角の敷地に木造住宅

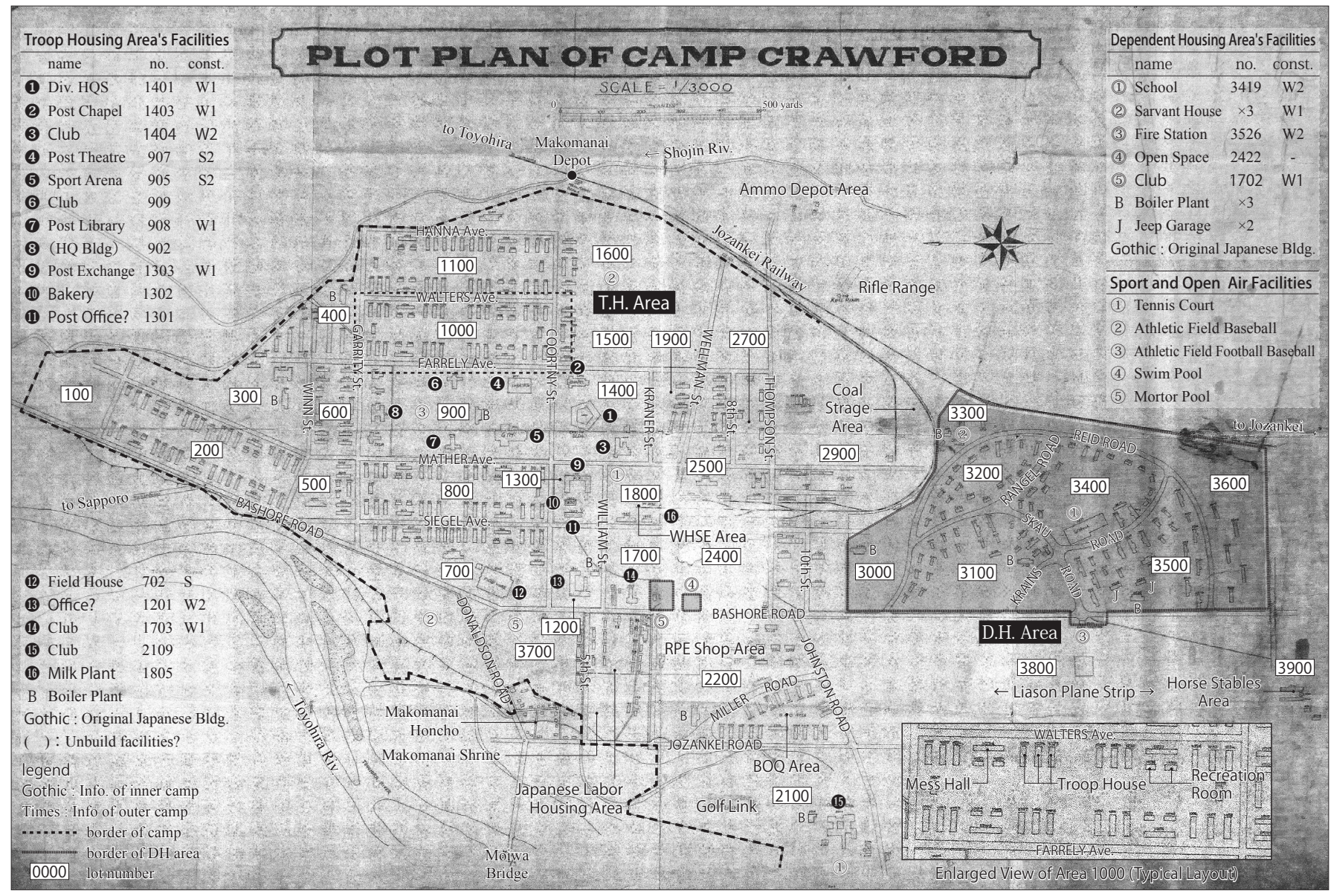

Fig.2 "PLOT PLAN OF CAMP CRAWFORD SCALE=1/3,000"

(Author addied informations from ref. 14, note 6 on the basemap (note 7) owned by Sapporo City Archive) 
と食堂がある.さらに，隣接する 2100 区には大成建設が設計・施工 したゴルフ場, (15将校クラブ (2100)，(4)プール，(1)テニスコート等 もある. ゴルフ場は北海道で唯一 18 ホールを備え,「真駒内基地の 付属施設でみごとなのは米軍専用のゴルフ場である」 ${ }^{8)}$ と, 米軍の 遺産と位置づける向きもある. この他, 種畜場の官舎等も確認できた. この様にキャンプ・クロフォードの施設配置は, 場内道路や農場施 設を活かしつつ, DH 地区と TH 地区を一体として計画された.

ちなみに, Fig.2の 3700 区の西は旧集落の真駒内本町で, 藻岩橋で 豊平川を跨ぎ石山街道（現国道 230 号）につづく. 町名の通り, こ こは真駒内発祥の地で, キャンプ・クロフォードの建設と共に人口 が増加し, 接収中には新鮮な野菜を求めに兵士らが訪れたという注 ${ }^{55)}$. 但し, 計画時と判断できる縮尺 1:3000の配置図（Fig.2）と竣工 間もない時期と判断できる配置図を比べると, 前者は真駒内神社を 含まないが後者は含んでいる．ここから真駒内神社自体は接収され なかったが，接収の範囲が変更したことがわかる.

\section{5. キャンプ・クロフォードの建築}

本章では, NARA 所蔵写真と『開拓使・道庁営繕 80 年の覚書き』から, 個々の建築について整理する. NARA 所蔵写真は, 撮影の年月日や 都市名, 施設名称等が記されている場合が多く, 当時の状況を把握 する上で有効である．但し，これまで建築の設計図書は見出せてお らず，平面や断面，寸法等の情報は概要に止まる.

5.1. 宿舎（DH）地区の建築

一般に, DHには 1946 年 6 月に示された平家の A-1, A-2, B-1,

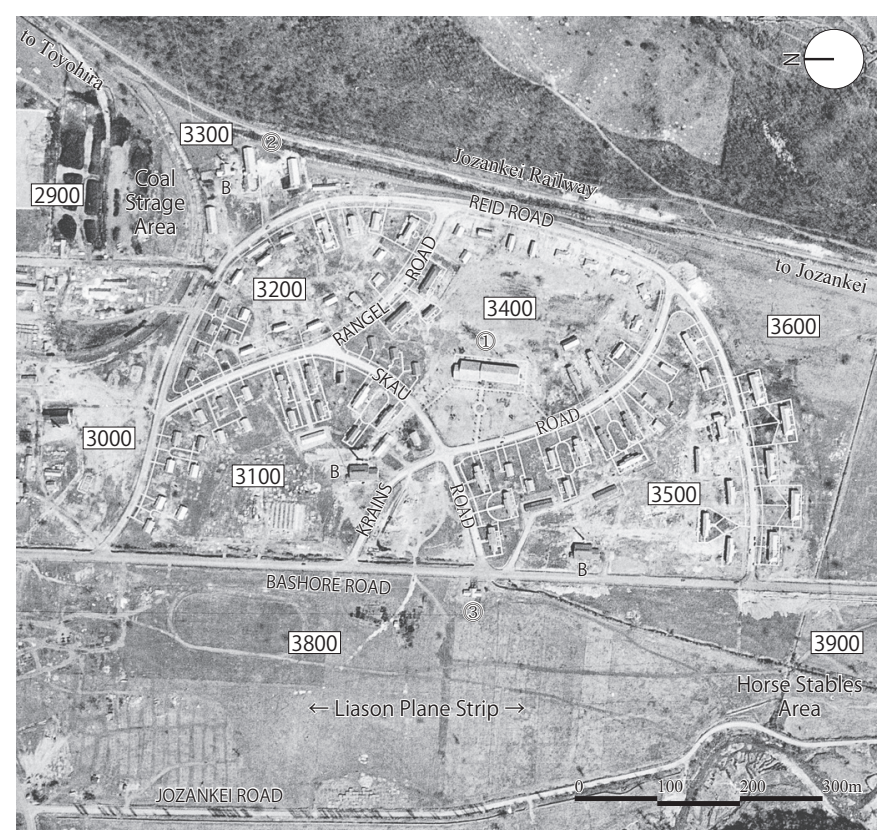

Fig.3 Airial View of DH area and its around, 1948 (UR246_CA-135, 22 Apr. 1948 owned by Geospatial Information Authority of Japan)

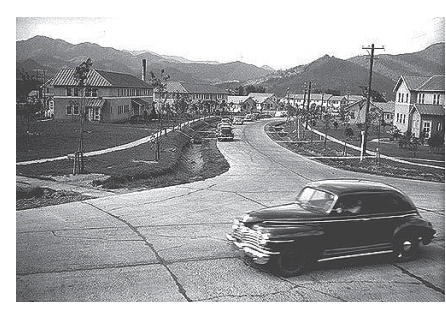

Fig.4 Townscape of D.H. area (owned by City Archives of Sapporo)

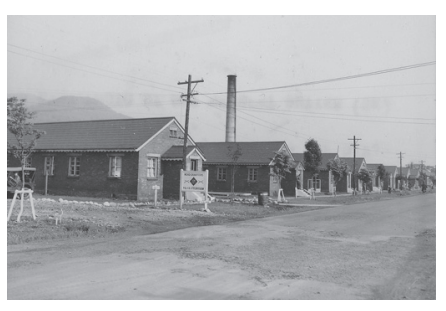

Fig.5 Townscape of T.H. area (31 May 1951, owned by NARA)

B-2, C-1 の 5つと，A-1a の様に A と B には小文字の「a」を付した 2 階建の 4 つの計 9 つの型がある ${ }^{3,5}$ (Table 3). 1 戸の床面積は B-2a が最大, A-1 が最小で, A より B の方が居住者の職位が高く, C は多 人数の家族用である. また, 景観に変化をつける為注 56$), 2 \sim 4$ 戸の DH を組合せ， I 型や $\mathrm{H}$ 型等の多様な住棟を用意したことは小泉らが 指摘する. また, 2.1 で触れた「家族住宅計画一般仕様書」によると, 住宅は木造平家か 2 階建て, 屋根は「セメン莫」か厚型スレート莫, 外壁はスタッコか下見板, 床は「楢縁甲板張」, 内壁と天井は「テッ クス張（一部プラスター仕上）」, 台所その他に一部造り付物入戸棚 を設けるのが共通の仕様である.しかし，「現地各部隊は当該建設地 区に適合する設計」という様に, 地域性による違いも認める ${ }^{3)}$.

キャンプ・クロフォードの DH については, 廣田が平均面積や共 通仕様, 型について「10 タイプを超え」等と簡単に触れるが, 個々 の床面積, 1 棟の戸数や棟数といった詳細は不明である. 本稿では, 接収解除時の DH の番号, 構造, 延床面積, 壁の仕上げを示す「一覧」 14) と, 配置図や空中写真, 真駒内団地建設時の土地区画整理図を照 合し，7つの型に準ずる平家と 2 階の 1，2，4 戸建の DH があること が把握できた（Table 4)。廣田によれば DH は木造在来構法で, 大成 建設と木田組を中心に施工された ${ }^{10}$. また, 写真から屋根は 4 戸建 の住棟に寄棟が確認できるが, 切妻が基本である. 外壁は廣田がス タッコ,「一覧」はモルタルとするが，色は白，屋根は鉄板の瓦棒葺 か一文字蒀で緑のペンキが塗られていた注 57). “DH”の写真から「セ メン莫」とはセメント栈瓦葺と理解できるが, キャンプ・クロフォー ドの DH の屋根が鉄板莫であるのは積雪寒冷地という「建設地区に 適合」させた為だろう。一方, Fig.7 で判断する限り内装は一般仕様 に準じていたと思われ，部屋の隅の管からスチーム暖房が備わって いたと判断できる。一般の日本人は立入禁止であったがときに見学 が認められ, 当時の日本人の生活水準を超えた機能や設備は「アメ リカ村」や「白亜の城」注58) と呼ばれた.

水洗便所やスチーム暖房の設置は全国共通の仕様である. キャン プ・クロフォードでは石炭ボイラーによる集中暖房が導入されたが, これは 1946 年 4 月 1 日に第 8 軍司令部が示した「将校抢よび家族宿

Table 3 Outline of DH, GHQ standard and Makomana

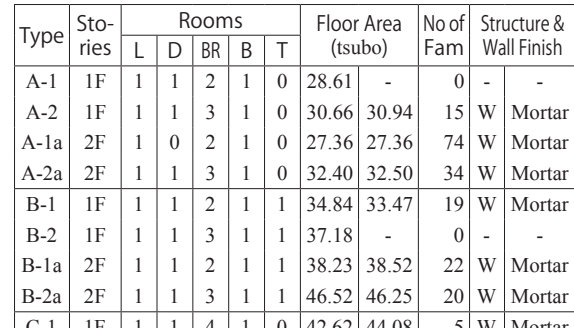

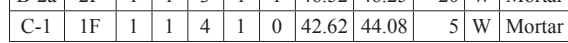
1.This table is made by ref.3 (p.45) and ref.14 2. in Rooms, L:living, D:dining, BR:bed, B:bath, K:kitchen and T:trunk 3.in Floor Area, left:GHQ's standard, right:Makomanai's for one family

\begin{tabular}{|c|c|c|c|}
\hline Type & \begin{tabular}{|l|} 
Fam \\
/Bldg
\end{tabular} & \begin{tabular}{|l|} 
No of \\
Bldg
\end{tabular} & $\begin{array}{l}\text { Roof } \\
\text { Type }\end{array}$ \\
\hline A-2 & 1 & 15 & G \\
\hline A-1a & 2 & 12 & G \\
\hline A-1a & 4 & 7 & G \\
\hline A-2a & 2 & 6 & G \\
\hline$A-1 a+A-2 a$ & 4 & 11 & G \\
\hline B-1 & 1 & 19 & G \\
\hline B-1a & 4 & 2 & G \\
\hline B-2a & 2 & 3 & G \\
\hline $\mathrm{B}-1 \mathrm{a}+\mathrm{B}-2 \mathrm{a}$ & 4 & 7 & $\mathrm{G}+\mathrm{H}$ \\
\hline $\mathrm{C}-1$ & 1 & 5 & $\mathrm{H}$ \\
\hline
\end{tabular}

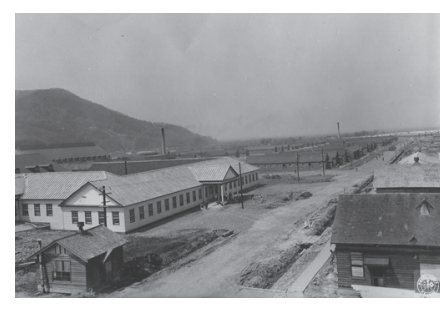

Fig.6 P.X. and Troop Housings (16 May 1947, owned by NARA)

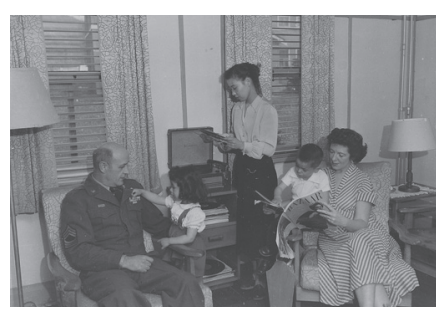

Fig.7 "In the Dependent Quarters" ( 25 May 1953, owned by NARA) 
舎の修理復旧に関する仕様概要」が「L 中央暖房により室温七○度 $\mathrm{F}$ に保ちうるようにすること」 ${ }^{3)}$ に準じたものだろう。『新札幌市史』 9) によると, 戦後の札幌市で最初に地域集中暖房が設けられたのは 日本住宅公団による 1967 年 10 月の円山北町であるから, キャンプ・ クロフォードの採暖方式は約 20 年早かったことになる.

この他, (1)学校（3419）は木造 2 階建の 730 坪で, 1947 年秋に竣 工 (10月 1 日開校)，9学級約 450 人が学んだという ${ }^{8)}$. また, (2)使 用人寄宿舎や(3)消防署 (3526), ボイラー室, ジープ車庫も木造である.

\section{2. 兵舎 $(\mathrm{TH})$ 地区の建築}

執務機能の内， (1師団司令部（1401）は，木造平家で白い外壁に 上げ下げ空を穿ち，瓦棒蒀の寄棟屋根を載せる．平面は米国国防省 を彷彿とさせる 1 辺 $46.5 \mathrm{~m}$, 梁間 $11 \mathrm{~m}$ の 5 角形である ${ }^{10)}$. 当初は 2 階建で計画したが， 3.2 で触れたアイケルバーガー中将の訪問で規模 を縮小した。また，12屋内訓練場（702, Fig.8）は，72×62mの平面 で，旧日本軍美幌航空隊格納庫用の鉄骨を転用した。基本設計は福 岡五一, 施工は大林組である. 元は北海道東部の積雪の少ない地域 の仕様の為, 札幌の気候を考慮して補強したが, 1955 年の豪雪で崩 壊したという ${ }^{10)}$. 内部は, 冬季の訓練を念頭に土間とした。

生活を補完する機能の内，2教会（1403 Fig.9）は梁間 11.8m，軒 高 $8.5 \mathrm{~m}$ のラテン十字の平面である. 特別建設局では設計できなかっ た為, 施工業者に内定済であった大成建設本社の「古典建築に明る い」人物に依頼したという。正面は尖頭アーチ, その両側の対になっ たジャイアントオーダー, 破れ破風という印象的な構成であるが, 洗練された意匠とは言い難い。また, 9 PX（1301）は，白い壁に瓦 棒葷の屋根を載せたコの字型平面である. 購買機能の他にスナック・ バーを併設し，防犯上の配慮と思われる空格子を備える.

(7図書館（908）は下見板の外壁に上げ下げ空を穿ち，瓦棒亘の切 妻屋根が載る析行 $34.5 \mathrm{~m}$, 梁間 $9 \mathrm{~m}$ の $\mathrm{T}$ 字型平面で, 高い天井の明る い開架閲覧室を持つ（Fig.10）。また， 4劇場（907, Fig.11）と6屋内 運動場（702）は，札幌近郊（現札幌市東区）の势珠航空隊格納庫の 材料を転用して建設した ${ }^{10)}$. 前者はアール・デコ調の正面で, 1 階 840 席, 2 階 270 席を持つ. 後者は軒にトップライト, 両側に 7 つドー マ空を持ち， 1 階にプールと小アリーナ， 2 階に大アリーナがある.

この他, 職位に応じたクラブもあった. その一つが種畜場最大で 1937 年建設の牛舎を転用した3クラブ（1404, Fig.12) である. 腰折

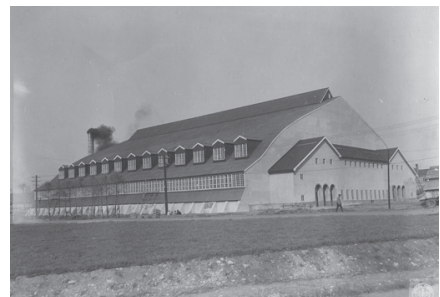

Fig. 8 "Field House" (16 May 1947, owned by NARA)

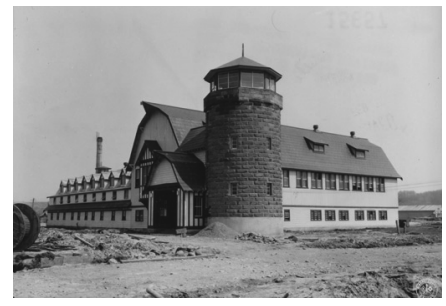

Fig.12 "The Enlisted Men's Club" (16 May 1947, owned by NARA)

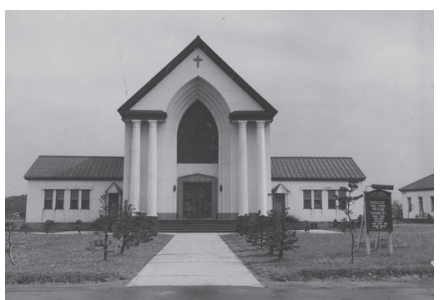

Fig.9 "Post Chapel" (31 May 1951, owned by NARA)

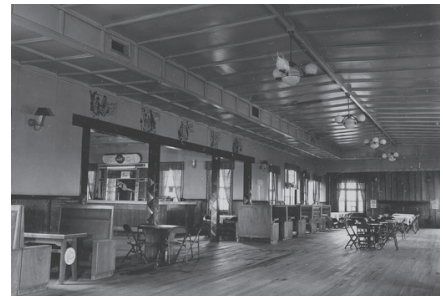

Fig.13 "The Lower Four Grade Enlisted Club" (31 May 1951, owned by NARA)

屋根と切妻屋根の 2 棟が $\mathrm{L}$ 字に交差し, 石造サイロを併設する. 2 階 は卓球やビリヤード等の娛楽施設で, ドーマ空から十分な採光を確 保する. また, 手動式のボーリング場もある ${ }^{\text {注 } 59)}$. 設計は福岡五一で, サイロは展望台になり, 天井は船底, 床はフローリングにボックス 席を並べたバーを持った（Fig.13）。また, (44下士官クラブ（1703）は, 大きな切妻屋根を持つハーフティンバーの建物で, 内部には中央を 折り上げ，白い合板と濃い色の木材による格子天井のバースペース がある.さらに，将校クラブ（施設番号不明）はステージを持つ天 井の高いホールやカウンター付きの食堂を持つ他，壁は白く大きな 開口で明るく，暖炉付きの重厚な造作の部屋もある（Fig.14）.

最後に，既に触れた通り TH は木造ながら外壁に煉瓦を用いる．屋 根は鉄板一文字莫の切妻で, 外壁に特徴があるが, 内部は合板張の 簡素な仕上である（Fig.15）。なお，確認し得る限り DH 地区，TH 地 区共に施設の空は 2 重で地域性が考慮された仕様といえる.

この様に，占領軍は様々な機能の施設を設けたが，全施設を新築 したのではなく既存の施設や材料を活かした。 また，寒冷地という 地域性を考慮した仕様も確認できた。この様にキャンプ・クロフォー ドは多様な機能を備えていたが，個々の施設の仕様は必ずしも贅沢 とはいえず，一時利用を前提としたキャンプを体現していた.

\section{6. 竣工以降のキャンプクロフォードの変容と位置づけ}

本章では，キャンプ・クロフォードの竣工から接収解除後の変化 を概観し，本稿の要点をまとめてむすびとしたい.

竣工から約 1 年半後の 1948 年 6 月 12 日, 全国で「従来にも増し て家屋の必要にせまられ」注60), キャンプ・クロフォードでは 1949 年に 30 棟 60 戸程を増築した. その後, 1950 年 6 月に朝鮮戦争が勃 発すると, 1 ～ 2 年の間に $\mathrm{DH}$ や TH がさらに増設された。また，朝 鮮戦争で部隊の交替が相次ぎ，9月には警察予備隊が入る等した.

その後，1954 年 6 月の朝鮮戦争休止による占領軍の引揚げに伴い 1955 年 3 月 31 日の TH 地区から段階的に接収が解除され，1959 年 12 月 14 日に完了した ${ }^{\text {注 } 61)}$. 跡地は，北の一部が陸上自衛隊真駒内駐 屯地, DH 地区が警察学校, 他は道営真駒内団地となったが, ゴルフ 場はそのまま用いられた. 1959〜1965 年に開発された真駒内団地は, 戦後の人口増加と住宅難を背景とした札幌の郊外開発で最初期のも のである. 札幌市は 1950 年代半ばに「グレートサッポロ」という都

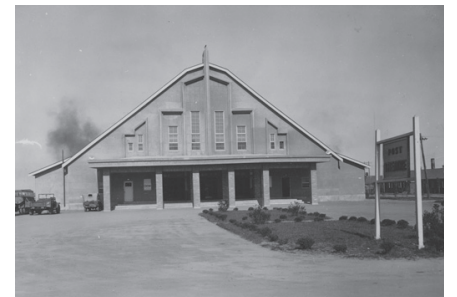

Fig.10 "The Post Theater" (21 Oct. 1947, owned by NARA)

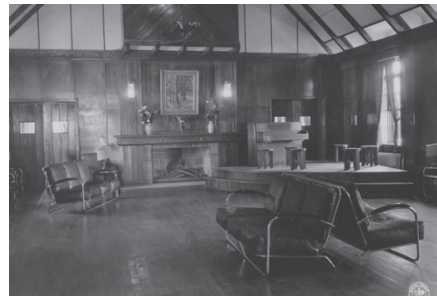

Fig.14 "The First Three Grades Club" (21 Oct. 1947, owned by NARA)

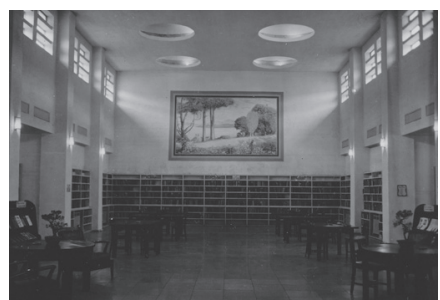

Fig.11 Post Library (21 Oct. 1947, owned by NARA)

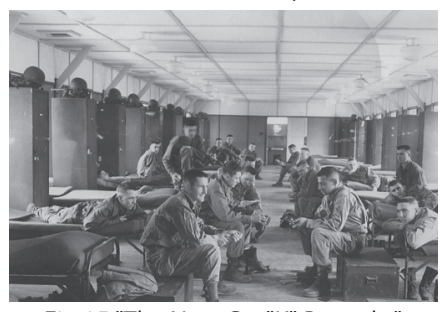

Fig.15 "The New Co. "K" Barracks" (16 May 1947, owned by NARA) 
市建設を目標に掲げたが停滞していた。そこで，急速な都市膨張を 受けて 1960 年に「主要事業一○計画」を策定した注 62 . 札幌市では 1963 年に 15,300 戸の住宅が不足し, 人口は 1960 年に 50 万, 1970 年 に 100 万人を超えた. 1961 年 5 月, 豊平町は札幌市に合併するが, こうした状況下で， 5,000戸，20,000 人の計画規模の真駒内団地が都 市施策に果たした役割は小さくなかったと思われる注63)。なお，マス タープランは東京大学の高山英華研究室が作成し, 幼稚園を単位と したコミュニティを計画した点に特徴がある.

その後, 1966 年 4 月に 1972 年冬季五輪が決定すると, DH 地区は 選手村となり, ゴルフ場には競技施設が建設された，大会後，選手 村は真駒内団地の一部をなし, 冬季五輪に併せて開通した地下鉄駅, 南区役所やショッピングセンター等からなる中核地区，ゴルフ場は 真駒内公園となり現在に至る。また，石炭暖房による公害問題を背 景に, 地域暖房のボイラープラントが南区役所の隣に建設され一帯 に供給された. 結果,『新北海道史』が「郊外に新しい都市が出現した」 と記す様に, 施設こそ更新されたが住宅地の性格は失わなかった上, 「小規模ながら一つの都市」という占領軍基地の性格をも受け継いだ. 戦災都市の中心部を占めた占領軍基地の跡地利用と比較すると, 例 えば横浜市は防火建築帯注 ${ }^{64)}$, 名古屋は都市公園, 神戸は市街地となっ ており, 占領軍基地が戦後の都市再開発に結びついた点で共通する が, 旧来の機能の継続性という点で札幌市は異なる.

最後に, 本稿の要点を 4 点にまとめ, むすびとする. 第 1 に用地 選定と立地条件で, 占領軍は市街地から独立し, 居住環境と衛生条 件の良好な札幌近郊の旧農場を接収してキャンプ・クロフォードを 新設した. 用地が郊外だったのは, 札幌市が非戦災都市だった為で もあった. また, 米ソ関係の緊張状態を背景に早期の竣工を求める中, 開墾済の用地は造成の手間を省くのに有効で, 既存の農場施設や場 内道路の利活用も有効に働いた.

第 2 に建設組織と工事で, 建設工事を民間業者が請負ったのは全 国に共通するが，地元業者を中心に施工組織を設立して一括で建設 を請負うという JV を彷彿とさせる独特の方法を採った．また，短い 工期や人材不足, 高い仕様要求が理由で工事は遅れたが, 資材の優 先的な調達で比較的早期に竣工することができた. さらに, キャン プ•クロフォードは占領軍全体の責任者をして「贅沢すぎる」と評し, 工費と DH の敷地規模が全国最大である点にそのことが窺えた.

第 3 に空間構成と施設配置で, キャンプ・クロフォードは地形に 即して高燥の東に DH と TH の両地区, 豊平川に近い西がそれを補完 する地区であった．DH は占領軍が示す要点に準じた構成である．－ 方， TH は既存の場内道路を基準に格子状に区画した上で施設を規則 的に配した. 要点に準じた DH の施設配置や既存施設の転用は, 全 国の占領軍基地に共通するが，DH 地区と TH 地区を一体として開発 し, 柔軟な対応で全体として必要施設を充足する点に独自性がある.

第 4 に建築で, キャンプ・クロフォードには全国の占領軍基地と 同様に一つの都市をなす様な施設があった，また，当時の日本人の 生活水準に照らせば機能や設備, 仕様は充実していたが, 基本的な 材料や意匠は標準的で, 旧日本軍施設の材料, 旧農場施設も転用す る等, 必ずしも贅沢ではなかった. それは, 一時利用を前提としたキャ ンプ（=基地）を体現していた.

この様に, 未開地であった真駒内は, 戦前に日本の近代農業を先 導する農場として開発されたが, キャンプ・クロフォード建設によっ
て一種の都市機能を有する住宅地として開発された．接収解除後の 再開発で札幌市の主要な郊外の一つとなったが, その素地は, 占領 軍による強制的な基地開発によって整えられた。 しかし，その検討 には占領期札幌の包括的な把握が必要で, 今後の課題としたい.

\section{謝辞}

本稿執筆にあたり, 北海道立文書館, 北海道立図書館, 札幌市公 文書館, 札幌市中央図書館, 北海道大学附属図書館, 国立公文書館, 外務省外交史料館にお世話になりました. 記して深甚なる感謝を申 し上げます，なお，本稿は JSPS 科研費 JP26249086（研究代表者：大 場修), JP19H02332（研究代表者：角哲）の成果の一部です.

\section{参考文献}

1) Kaku, S., Oba.O., Tamada, H., Sunamoto, F., Murakami, S., Osada, J.: A historical study on types and trens of alied buildings by GHQ in Sapporo, Hokkaido, Summaries of Technical Papers of Annual Meeting, Architectural Institute of Japan, History and Theory of Architecture, pp. 919-920, 2016. 7 (in Japanese) 角哲・大場修・玉田浩之・砂本文彦・村上しほり・長田城治 : 北海道札幌 市における進駐軍接収施設の種類と傾向について 占領下日本の都市・住宅 に関する研究 その 6 , 日本建築学会大会学術講演梗概集建築歴史・意匠, pp. 919-920, 2016. 7

2) The editorial com. for the history of occupation army's procurement: The history of occupation army's procurement -key of occupation army's procurement-, research section of general affairs dept. of public procurement service, 1956 (in Japanese) 占領軍調達史編さん委員会 : 占領軍調達史 - 占領軍調達の基調 -, 調達庁総務 部調査課, 1956

3) The editorial com. for the history of occupation army's procurement: The history of occupation army's procurement -about consttuction-, research section of general affairs dept. of public procurement service, 1959 (in Japanese) 占領軍調達史編さん委員会 : 占領軍調達史 部門編 - 工事 -, 調達庁総務部調 査課, 1959

4) Engineer Section FEC: Dependents Housing Japan \& Korea, published year unknown

5) Japanese Staff-Design Branch OCE GHQ AFPAC Industrial Arts Institute-Ministry of Commerce and Industry: Dependents Housing Japan \& Korea, Gizyutsu Siryo Kankokai, 1948

6) Sunamoto,F., Oba,S., Tamada,H., Kaku,S., Osada,J. and Murakami,S.: A study on condition of procurement of Miyajima hotel (tax training center, Hiroshima branch), AIJ Journal of Technology and Design, no. 62, pp. 383-388, 2020. 2 (in Japanese) 砂本文彦・大場修・玉田浩之・角哲・長田城治・村上しほり : 宮島ホテル (税 務講習所広島支所) の接収と取り扱いついて, 日本建築学会技術報告集 62 号, pp. 383-388, 2020. 2

7) Murakami, S., Oba, O., Sunamoto, F., Tamada, H., Kaku, S. and Osada, J.: The aspect of dependent housing and miritary dispositions in the occupied Japan, Journal of Architecture and Planning (Transactions of AIJ), no. 739, pp. 2441-2450, 2017. 9 (in Japanese)

村上しほり・大場修・砂本文彦・玉田浩之・角哲・長田城治 : 占領下日本 における部隊配置と占領軍家族住宅の様相, 日本建築学会計画系論文集 739 号, pp. 2441-2450, 2017.9

8) Okuda, J.: U.S. army's history in Hokkaido, 1961 (in Japanese) 奥田二郎: 北海道米軍太平記 黒と赤の日誌, 1961

9) Board of education, Sapporo: New history of Sapporo vol.5 common view 5-1, Sapporo city, 2002 ( in Japanese)

札幌市教育委員会 : 新札幌市史 第五巻 通史五（上）, 札幌市, 2002

10) Hirota, M.: The note for the building and repair section of Kaitakushi and Hokkaido gov., Do-Sekkei, Co.Ltd., 1997

越野武, 角幸博監修, 廣田基彦: 開拓使・道庁営繥 80 年の覚書き, 北海道建 築設計監理株式会社, 1997

11) Hokkaido government: New history of Hokkaido vol.6 common view 5, Hokkaido prefecture, 1977 ( in Japanese) 北海道: 新北海道史第六巻通説五, 北海道, 1977.

12) Hokkaido govt.: The documents for director general's succession of affairs, owned by The Archives of Hokkaido, 1946. 2 (in Japanese)

北海道庁 : 昭和二十二年二月長官事務引継 其の一, 北海道立文書館蔵, 1947.2

13) Hokkaido govt.: The documents for director general's succession of affairs, owned 
by The Archives of Hokkaido, 1946. 4 (in Japanese)

北海道廳 : 昭和二十二年四月長官事務引継書, 北海道立文書館蔵, 1947.4

14) Hokkaido govt.: The reference for requisition of old Makomanai facilities, owned by The Archives of Hokkaido, 1946-1954（in Japanese)

北海道庁 : 旧真駒内施設接収関係, 北海道立文書館蔵, 1946-1954

15) The general affairs div. of minister's secretariat:About construction of allied forces, owned by Diplomatic Archives of the Ministry of Foreign Affairs of Japan, 1945. 9-1949. 3 (in Japanese)

大臣官房総務課 : 連合軍に関する設営関係雑件, 外務省外交史料館蔵, 1945 11-1949. 3

16) The general affairs div. of minister's secretariat:About construction of allied forces, owned by Diplomatic Archives of the Ministry of Foreign Affairs of Japan, 1945. 9-1950. 5 (in Japanese)

大臣官房総務課：連合軍に関する建設関係，外務省外交史料館蔵，1945.91950.5

\section{注}

注 1) 秋尾沙戸子 : ワシントンハイツ GHQ が東京に刻んだ戦後, 新潮社, 2011 等

注 2）小泉和子, 高婁昭, 内田青蔵: 占領軍住宅の記録（上）日本の生活スタイ ルの原点となったディペンデントハウス, 住まいの図書出版局, 1999

注 3）本稿は文献 1 の一部を大幅に加筆し，修正したものである。

注 4）喜田信代, 羽深久夫 : キャンプ・クロフォード (米軍真駒内基地) の兵舎 建築について, 日本建築学会大会学術講演梗概集, pp.443-445, 1998.7 や喜田 信代, 本間博文, 羽深久夫 : キャンプ・クロフォード（占領軍真駒内基地） の建設概要について, 日本建築学会北海道支部研究報告集 No.70, pp.645648, 1997.3 があり, 前者は実測調査, 後者は聞取り調査が主の報告である.

注 5）石川洋介・角幸博・小澤丈夫・石本正明による北海道真駒内種畜場にお ける GHQ 接収施設の使用・解体について, 日本建築学会大会学術講演梗概 集,pp.399-400, 2011.7 と北海道における GHQ の接収・返還過程について, 日本建築学会北海道支部研究報告集 No.84, pp.663-666, 2011.7 があり, 前者 は転用された種畜場施設, 後者は北海道全域の接収施設を俯瞰する中でキャ ンプ・クロフォード全体の概要に触れている.

注 6)「米軍駐留時代の真駒内（昭和 25 年）縮尺 : 1/6000」(請求番号 297)

注 7)「PLOT PLAN OF CAMP CRAWFORD SCALE=1/3,000」（同 1454）

注 8）本稿では主に UR246_CA-134 とUR246_CA-135（1948.4.22 撮影)，MHO61-3B_C7-896 (1961.6.2 撮影)，MHO-61-3B_C8-225(1961.5.26 撮影）の 4 枚を用いた。

注 9) NARA で RG:SC111 所収の札幌関連の写真収集した.

注 10）神奈川県立川崎図書館の社史コーナーを中心に, 1945 年の工事受注額 上位 30 社の建設業会社史を中心に関連資料を閲覧した.

注 11）詳細は文献 2, p.199-203.

注 12) 文献 8,pp.117-119, 千歳市史編さん委員会 : 増補千歳市史, 千歳市, 1983 等

注 13$) 14$ 戸 58 人のスタッフのうち 10 戸 38 人は立退の必要があることが窅える.

注 14) 福岡は, 北海道の技師で 1934 年 6 月に「北海道の建物の姿」(『建築雑誌』 1934.9) と題した講演, 占領軍が接収した札幌グランドホテルの設計（1939） の他, 1940 年 9 月に落藤藤吉や吉田三郎平らと北海道建築協会を設立して 機関誌『北海道建築』を刊行し，モデル寒地住宅建設（1941）や農家住宅 設計協議（1942）を実施する等, 戦前の業界で重要な役割を担っていた.

注 15）角哲, 大場修, 砂本文彦, 玉田浩之, 村上しほり, 長田城治：日本の建設 業会社史にみる占領期の設計・施工業務に関する試論, 日本建築学会北海 道支部研究報告集, pp.515-518, 2018.6 で, 日建設計や横河工務所が 1950 年 代に設計協力していることを把握した,

注 16）政府の占領軍への陳情の詳細については文献 2,pp.180-191

注 17）この推計は「仙台特別建設出張所支部設置の件」(1946.4.19), 文献 16, p.77, 80

注 18) 北海道庁: 北海道庁種畜場沿革誌, 北海道庁, 1900 等

注 19）豊平町月寒には 1896 年設置の第 7 師団の施設があり, 沿革は豊平町史編さ ん委員会 : 豊平町史, 豊平町役場, pp.322-334, 1959, 等.

注 20)北海道建設新聞社 : 風雪の百年 - 北海道建設業界史 -, 北海道建設新聞社, p. 224,1970

注 21）札幌建設業協会創立 100 周年記念事業実行員会記念誌編纂部会 : 札幌建 設業協会 100 年史, 札幌建設業協会, p.69,2016. この他，文献 10, p.204 等.

注 22）角哲, 大場治, 村上しほり, 砂本文彦, 玉田浩之, 長田城治: 名古屋市に おける占領軍家族住宅の施設の種類とその配置, 日本建築学会北海道支部 研究報告集, pp.407-410, 2019.6

注 23）村上しほり : 神戸 闇市からの復興 占領下にせめぎあう都市空間, 慶應 義塾大学出版会, 2018

注 24）谷代久恵: 真駒内物語, 北海道新聞社, 2002, p.86にも廣田の推察を踏ま えた記述がある。
注 25）三沢は飛行場とDH100戸, 鹿屋の飛行場.

注 26）前掲占領軍住宅の記録（上）,pp.84-85 で，東京のグランドハイツ（成 増地区）の中央の道路を旧日本軍の滑走路を活かしたものと推察している.

注 27）玉田浩之, 大場修, 砂本文彦, 角哲, 村上しほり, 長田城治 : 占領軍家族 住宅「皇子山ハイツ」の建設経緯と跡地利用 占領下日本の都市・築に関す る研究その 8, 日本建築学会大会学術講演梗概集, pp.923-924, 2016.8

注 28）土木工業協会, 電力建設業協会 : 日本土木建設業史, 株三秀舎, p. 402,1971

注 29）前掲日本土木建設業史, p.402 では，合理化を目的に占領軍，戦災復興 院の勧めで「特建技術団（Architectural Engineering Company）という任意団 体」を組織したという (1947.5.31 解散).

注 30）前掲日本の建設業会社史にみる占領期の設計・施工業務に関する試論

注 31）前掲札幌建設業協会 100 年史,pp.69-70

注 32）前掲日本土木建設業史, p.461

注 33）前掲札幌建設業協会 100 年史,p.70. 同様の指摘は，北海道建設業協会 100 年史編集委員会: 北海道建設業協会 100 年史, 北海道建設業協会, p.76, 2016 等.

注 34）北海道とともに百年一大成建設株式会社, 大成建設株式会社, p.33. な 抢, 1947 年 9 月刊行の小島國平 : 札幌商工案内, 札幌商工案内, 1947 に大 成建設株式会社札幌支店」の協賛広告（p.134）があり，住所を「札幌郡豊 平町字真駒内」と記すから, 同社が当該工事を重視していたと理解できる. 注 35）社史発刊準備委員会: 大成建設社史, 大成建設株式会社, p.436, 1963

注 36）前掲風雪の百年一北海道建設業界史一, 北海道建設新聞社, p. 225,1970

注 37) この他, 前掲真駒内物語, p.100 等

注 38）遠藤明久：北海道住宅史話（下）, 住まいの図書出版局,pp.29-41, 1994

注 39）前掲の真駒内物語, pp.93-97

注 40）持ち出しが必要なのは, 工期に照らし, 支給が間に合わない為であった.

注 41）なお,引込線は建設工事完了後に撤去の予定であったが継続利用された.

注 42）前掲日本土木建設業史, p.403

注 43）前掲風雪の百年一北海道建設業界史一, p.260

注 44)この他, 村松貞次郎: 日本近代建築技術史, (株彰国社, 1976, pp.175-176 が, 「戦後の建築施工術のもっとも大きな特徴は ... 目ざましい機械化の進展で ある. それらの契機としては，1）占領軍基地等の工事でアメリカ貸与の近 代的な建設機械の操作に習熟したこと」と記す様に, 共通認識といえる.

注 45)文献 8, 10 の他, 札幌市史編さん委員会 : 札幌百年のあゆみ, 札幌市, p.448, 1970 等

注 46）文献 8,10 , 奥田二郎 : 道政風雲録一戦後十年一, 双樹社, p.77, 1959 等

注 47）高橋昭夫 : 証言 北海道戦後史田中道政とその時代, 北海道新聞社, p. 152,1982

注 48）文献 2, p.206. 占領軍としては, 兵舎や飛行場が作戦上重要な為, 設計 や施工, 竣工検査を詳かにしなかったという.

注 49）主に注 6 と注 7, 文献 14 所収 "CAMP CRAWFORD JAP 253" を参照した.

注 50）砂本文彦, 大場修, 玉田浩之, 角哲, 長田城治, 村上しほり：占領期岡 山に拈りる接収住宅に関する研究, 日本建築学会中国支部研究報告集, pp.945-948, 2016.3 等

注 51）前掲占領軍住宅の記録（上）,p.74

注 52）定山渓鉄道東の丘陵地は油槽等の附属施設用地, DH 地区の南は演習地 であったが, 本稿では割愛した.

注 53）本稿では, 注 8 の空中写真, 注 68 の配置図の他, 北海道立文書館所蔵 の北海道庁 : 昭和三十三年度 旧真駒内種畜場財産返還関係 (A11-3/505) 所 収の接収解除時のリスト, 土地区画整理事業認可申請（A11-3/1033）の「設 計変更図」（1966.3.10）を元に当初計画の竣工時までの棟数と戸数を判断し たため, 資料の作成年や種類によって増減があることを付言しておく.

注 54）なお, 解体建物 119 棟のうち 96 棟は杉山組, 23 棟は軍が取壊した. また, 郷土史真駒内編纂委員会 : 郷土史真駒内, 郷土史真駒内編纂委員会, 1977 は 「21 棟を残して取り壊されてしまい」p.55 と記す.

注 55) 前掲真駒内物語, p.112

注 56）前掲占領軍住宅の記録（上）, p.130

注 57）真駒内街路灯組合編: 真駒内団地史街路灯と地域の歩み, p.7, 2016

注 58）高橋昭夫 : 証言 北海道戦後史 - 田中道政とその時代 -, 北海道新聞社, pp.74-75, 1982

注 59)倉島齊: わたしの戦後体験 米軍基地キャンプ・クロフォード,「新札幌市史」 機関紙札幌の歴史第 41 号, 札幌市教育委員会文化資料室, pp.40-47, 2001

注 60）個人住宅関係, H.2.1.0.4 連合軍による土地建物その他の接収及び解除関 係（第一巻）, pp. $57-58$

注 61）前掲真駒内団地史 街路灯と地域の歩み,pp.7-9

注 62）この計画は, 後に見直されて 1965 年に「札幌建設六年計画」, 冬季五輪 開催決定に伴い1966 年に「札幌建設五年計画」となった。

注 63） 1975 年の居住人口は 25,280 人と計画人口を超えていた.

注 64) 木島繁治: 接収解除の歩夕,横浜市総務局渉外部, 1997 等 


\title{
A HISTORICAL STUDY ON CONSTRUCTION PROCESS AND ITS FEATURES OF CAMP CRAWFORD ON GHQ'S OCCUPIED DAY IN SAPPORO
}

\author{
Satoru KAKU ${ }^{* 1}$, Osamu OBA*2, Fumihiko SUNAMOTO*3, \\ Hiroyuki TAMADA ${ }^{* 4}$, Shihori MURAKAMI ${ }^{* 5}$ and Joji OSADA *6 \\ ${ }^{* 1}$ Assoc. Prof., Graduate School of Design and Architecture, Nagoya City Univ., Ph.D. \\ *2 Prof., Faculty of Life and Environmental Sciences, Kyoto Prefectural Univ., Dr.Eng. \\ *3 Prof., Faculty of Home Economics, Kobe Women's Univ., Dr.Eng. \\ ${ }^{*}$ Assoc. Prof., Faculty of Media and Arts, Otemae Univ., Ph.D. \\ ${ }^{* 5}$ Visiting Researcher, Graduate School of Human Life Science, Osaka City Univ., Ph.D. \\ ${ }^{* 6}$ Lect., Dept. of Human Life Studies, Koriyama Women's Univ., Dr.Eng.
}

keywords:After World War II, Hokkaido Prefecture, Sapporo, GHQ, occpied and Camp Crawford

The purpose of this article is to clarify the construction process and features of Camp Crawford in Makomanai, Sapporo. It was named after Joseph Ury Crawford, advisor and U.S. railway engineer of the Hokkaido development commission (Kaitakushi). Upon the occupation of Japan, the general headquarters (GHQ) set the 9th corps, 8th army's headquarters in Sapporo, chosen primarily because of Hokkaido's location. Several notable cities in Japan were war damaged, hence had little facility stocks. Sapporo, on the other hand, was intact and had enough supplies. These were essential aspects in establishing the headquarters in Sapporo.

GHQ ordered the Japanese government to construct 20,000 dependent housings (DH) in March 1946. This proved difficult because building materials were scarce, so some construction projects were stopped. However, deemed by the government as essential in the Cold War due to its strategic location, Camp Crawford's construction continued and was erected quickly in Sapporo.

GHQ appropriated the land of the Hokkaido Animal Husbandry Experimental Station Makomanai as the site. It was located south of Sapporo's city center, about 4-6 kilometers away, upstream of Toyohira river. Jozankei railways was at the eastern side. These proved valuable to maintaining good living conditions and sanitation. Also, beneficial for swift construction.

Private contractors organized a special union to construct the new camp. The union received the contract as a single unit. This approach was outstanding at that time since it can be recognized as the initial stages of a joint venture (JV) agreement. The JV was definitively established during the 1950's in Japan. Construction was delayed but eventually completed as supply of building materials for this particular camp was a priority. 8th army head Eichelberger evaluated it as "too expensive." Consider though, that the camp had several facilities and covered a vast plot of land. Also, the land area for one DH was the largest among all camps in Japan.

The DH and troop housing (TH) were developed concurrently, a unique feature here since, typically in GHQ's camps across Japan, these would be built separately. This camp's site plan was influenced by topography and old facilities. TH and DH areas were situated in the eastern part of the site where it was dry and higher than the west. The service facilities were on the west amidst gently rolling terrain. TH was on the upper section of the site's eastern part, laid out on a grid using the old farm road. Below it, the DH was arranged on curved roads, following GHQ standard. Several facilities were added, making the camp almost a small city.

TH area had, among others, an office, PX, bakery, church, theater, clubs, library, gym, sports grounds, and golf link. DH area had detached and row houses using GHQ standards, except for the roof material. Instead, the roof was finished with sheet iron, characteristic of the cold region, and contributing to high costs. However, the GHQ used existing facilities and new buildings were simple. The camp was generally using excellent specifications when compared to Japanese buildings at that time.

After derequisition, late 1950 's, the site was transformed to the Japan Self-Defense Force Base and a prefectural residential area, Makomanai Danchi. The DH area was once used as Olympic village, the golf link for stadiums. Camp Crawford is the foundation of present residential suburbs. 